\title{
Limestone and Oyster Shell for Brown Layers in Their Second Egg Production Cycle ${ }^{1}$
}

-Author(s)
Pizzolante $\mathrm{CC}^{2}$
Kakimoto $\mathrm{SK}^{2}$
Saldanha ESPB
Laganá $\mathrm{C}^{2}$
Souza HBA
Moraes JE2
1 Research project funded by FAPESP.
2 Scientific researchers of the APTA Regional/
DDD-APTA/SAA-SP.
3 Prof. of the Department of Technology,
FCAV/UNESP - Jaboticabal.

-Mail Adress

CC Pizzolante

APTA

Caixa Postal 105

17.380-000. Brotas, SP, Brazil.

E-mail: ccp@apta.sp.gov.br

\section{- Keywords}

Egg quality, levels, minerals, particle size, performance, sources.

\section{-Acknowledgements}

The authors thank FAPESP for funding this experiment; Kakimoto farm for manufacturing the experimental diets; Mr. José Cláudio Caldeira, on behalf of Cysy Mineração Ltda, for donating the oyster shell; Mr. José Roberto Medina Garcia and Mr. Eduardo Piber Neto, from the Layer Department of Multimix Nutrição Animal Ltda., for helping with the laboratory analyses, and Marcelo Surian Checco from Tortuga for his friendship and support.

\begin{abstract}
This study aimed at evaluating the effect of dietary calcium levels and the replacement of calcium sources with different particle size compositions on the performance and egg quality of brown layers in their second egg production cycle. A randomized block experimental design was applied with 12 treatments in a $3 \times 4$ factorial arrangement: three calcium levels $(2.6,3.2,3.8 \%)$ and four combinations of calcium sources (1-100\% fine limestone (FL), 2- 50\% FL + 50\% coarse limestone (CL), 3- 50\% FL and 50\% oyster shell (OS), 4- 50\% FL and 25\% CL+ $25 \%$ OS), with six replicates of eight birds each. Calcium sources were analyzed for geometric mean diameter (GMD) and in-vitro solubility. The following performance and egg quality parameters were evaluated: egg weight (EW, g), egg production (\% Eggs), egg mass (EM \%), feed intake (Fl g), feed conversion ratio (FCR kg/dz and FCR kg/kg), mortality (\% Mort.), specific egg gravity (SG), percentages of yolk (Y\%), albumen (Alb\%) and eggshell (ES\%), eggshell thickness (EST), eggshell breaking strength (BS), eggshell weight per surface area (EWSA), Haugh unit $(\mathrm{HU})$, yolk index $(\mathrm{YI})$ and yolk color. Performance and internal egg quality were not affected by the treatments ( $p>0.05)$. Blocks had a significant effect on $(p<0.05) \mathrm{Fl}$ and FCR $(\mathrm{kg} / \mathrm{dz}$ and $\mathrm{kg} / \mathrm{kg})$. Treatments significantly influenced external egg quality, which improved as dietary calcium levels increases and when up to $50 \%$ fine limestone was replaced by combinations of coarse limestone with oyster shell.
\end{abstract}

\section{INTRODUCTION}

Modern commercial layer strains have become increasingly productive and demanding in terms of management, health, environment, and nutrition. Studies have been developed to improve not only animal productivity, but also the quality of final products.

In the case of layers, their final product is eggs for human consumption. The main concern of farms related to egg quality is eggshell quality. After the eggshell is formed, this "package" cannot be remade, and eggshell defects will result in product downgrading due to the presence of cracks, deformities, and irregularities, with consequent significant economic losses (Ito et al., 2006).

Kussakawa et al. (1998) mentioned that, in order to be marketed, the eggshell of eggs must be strong enough to resist lay, collection, grading, and transport until they reach the final consumer. However, according to Leeson \& Summers (2005), approximately 7 to $8 \%$ of the eggs produced present some kind of eggshell damage - caused by different reasons - that directly affects egg marketing. Moreover, eggshell integrity is essential to preserve internal egg quality, the physical, chemical, biological, and functional characteristics of egg proteins occur after lay. 
Pizzolante CC, Kakimoto SK, Saldanha ESPB, Laganá C, Souza HBA, Moraes JE

Calcium is an essential mineral for eggshell quality, and it is the main component of the eggshell, which consists of $95 \%$ of calcium carbonate (Miles, 1993). Adequate calcium supplementation to layer diets is critical, as its deficiency may cause reductions in egg size and production, poor egg quality, with consequent high percentage of broken eggs and increased layer mortality (Dell'Lsola \& Baião 2001; Geraldo et al., 2006).

There has been increasing interest in research on the calcium metabolism of layers in their second production cycle. According to Oliveira (2002), these birds have excellent production of large and extra size eggs, but due to their limited calcium storage capacity, the eggs present thin eggshells. In addition, although there is extensive research on the effects of calcium sources and levels on first-cycle layers, there are few studies on the nutritional requirements of second-cycle layers, which are not even included in the NRC (1994). According to Rodrigues (1995), the information on optimal calcium levels for layers after forced molting are still subject of discussions, including in relation to the calcium form to be added in the feed.

The most commonly calcium sources added to layer diets are calcitic limestone and oyster shell, and studies on adequate calcium levels, sources and particle size have contributed to improve egg quality through improvements in eggshell synthesis and bone development of modern layers. Several studies have been carried out on the physical and chemical characteristics of calcium sources (Roland \& Farmer, 1984; Bertechini \& Fassani, 2001).

Calcium particle size may influence the availability of this mineral to poultry. According to Miles (2000), as the fine particles of limestone are readily solubilized during the night, bones are the main source of calcium for eggshell synthesis. When larger limestone particles, with lower solubility, are used, the digestive tract of layers is able to maintain calcium levels even during the night as its gradual solubilization and availability maintain adequate calcium blood levels.

Leeson \& Summers (1997) and Junqueira \& Rodrigues (2004) observed that coarse limestone promotes higher calcium retention in the gizzard, making it slowly and uniformely available during the period of eggshell synthesis, with consequent higher eggshell strength and egg and eggshell weights. However, Roland \& Bryant (1999) commented that the replacement finely-ground limestone by coarser limestone should not be higher than $50 \%$ as otherwise feed intake is affected.

\section{Limestone and Oyster Shell for Brown Layers in Their} Second Egg Production Cycle

Jardim Filho et al. (2005) evaluated combinations of fine and coarse limestone of 30 and $40 \%$ and observed an improvement in eggshell quality, but observed that combinations lower or higher than this percentage resulted in worse eggshell quality. The authors concluded that the absence of coarser limestone or oyster shell particles in the diet negatively affects eggshell quality. However, layer feeding behavior may be affected when very large limestone particles are used (Fassani et al., 2004).

Fassani (2003) evaluated the mineral composition and in-vitro solubility of different calcitic limestone sources with different particle sizes produced in the state of Minas Gerais, Brazil, and observed variation in their mineral composition. He also verified that their invitro solubility changed according to their geographic origin and that it was influenced by their particle size. Ito (2006) also found that limestone sources derived from different regions presented different solubility and calcium content. According to Roland \& Bryant (1999), factor such as limestone density and purity may influence its solubility, consequently affecting calcium availability to the birds.

Murata etal. (2009) observed better egg production, feed conversion ratio, egg weight, and eggshell strength and thickness as dietary calcium levels increased (3.75, 4.15 and $4.55 \%)$, but the different combinations of fine and coarse limestone (0, 25, 50, 75 and 100\%) did not influence the studied parameters.

Considering the very diverse information provided in literature, further studies are required to characterize calcium sources in order to prevent egg production or quality losses. Therefore, the present study aimed at evaluating the effect of calcium levels and the use of fine and coarse limestone and their combinations with oyster shell on the performance and egg quality of brown layers in their second product cycle.

\section{MATERIALS AND METHODS}

The experiment duration was 112 days, and aimed at evaluating the effect of calcium levels and the replacement of calcium sources with different particle size compositions on the performance and egg quality of brown commercial layers in their second egg production cycle.

Birds were housed in two layer houses with 36 battery cages each placed in two double rows separated by a central aisle. The galvanized iron cages were $1.00 \mathrm{~m}$ long, $0.45 \mathrm{~m}$ deep and $0.40 \mathrm{~m}$ high, and had an internal transversal $0.50 \mathrm{~m}$ division, which 
Pizzolante CC, Kakimoto SK, Saldanha ESPB, Laganá C, Souza HBA, Moraes JE

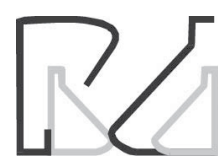

allowed housing four birds per cage division and eight birds per cage, totaling 288 birds per house. Each cage was equipped with a cup drinker and a trough feeder placed in front of the cage.

A total number of 576 Hy-Line Brown layers was submitted to forced molting by fasting and no artificial light until they lost approximately $25 \%$ of their body weight, which occurred after 14 days. Water was supplied ad libitum during molting, and birds were gradually re-fed with ground corn until day 28 . At 92 weeks of age, after reaching $50 \%$ egg production, birds were submitted to the experimental treatments.

Feeds were supplied ad libitum and distributed in the morning and in the evening. A lighting program of 17 hours of light per day was adopted. Environmental temperature was daily recorded using a maximumminimum thermometer placed in the center of each house.

The experimental diets were iso-nutritive and were formulated on corn and soybean meal basis according to the nutritional requirements provided in the genetic line manual and to the raw material values in the tables of Rostagno et al. (2005), except for calcium levels, which were supplied according to the experimental treatments (Table 1).

Particle sizes of the used calcium sources were classified as fine (limestone with particle size lower
Limestone and Oyster Shell for Brown Layers in Their Second Egg Production Cycle

than $0.5 \mathrm{~mm}$ ) and coarse (limestone or oyster shell with particle size higher than $2.0 \mathrm{~mm}$ ). Limestone and oyster shell particle sizes were determined by collecting approximately $1 \mathrm{~kg}$ of each source, which was duly identified and sieved through a set of ABNT sieves (numbers 5, 10, 16, 30, 50, 100 and mesh sizes (mm) of $4,2,1.20,0.60,0.3$ and 0.15 (Zanotto \& Bellaver, 1996). Particle size was characterized according to treatment and particle uniformity, and expressed as geometric mean diameter (GMD). GMD has a positive correlation with particle size.

The solubility of calcium sources was determined by the method of weight loss percentage, which consists in weighing samples of $2.0 \mathrm{~g}$, which are immersed in a hydrochloric acid solution at $0.2 \mathrm{~N}$ heated to $32^{\circ} \mathrm{C}$ for $15 \mathrm{~min}$ under slight agitation. Samples are then filtered in paper filter, dried in an oven at $60^{\circ} \mathrm{C}$ for $20 \mathrm{~h}$ and weighed in a digital scale to calculate the percentage of in-vitro limestone solubility (Zhang \& Coon, 1997).

Birds were distributed in a random block experimental design with 12 treatments in a $3 \times 4$ factorial arrangement, with three calcium levels and four particle size compositions, with eight birds per experimental unit, totaling 576 birds. The experimental treatments are presented in Table 2.

The following performance parameters were evaluated: egg weight (g), egg production (\%), egg

Table 1 - Ingredient and calculated composition of the experimental diets.

\begin{tabular}{|c|c|c|c|c|c|c|c|c|c|c|c|c|}
\hline Ingredients & T 01 & T 02 & T 03 & T 04 & T 05 & T 06 & T 07 & T 08 & T 09 & $\mathrm{~T} 10$ & T 11 & $\mathrm{~T} 12$ \\
\hline Corn & 63.090 & 63.088 & 63.203 & 63.145 & 64.250 & 64.248 & 64.393 & 64.320 & 65.409 & 65.407 & 65.583 & 65.494 \\
\hline Soybean meal $45 \%$ & 19.806 & 19.805 & 19.903 & 19.853 & 20.795 & 20.794 & 20.918 & 20.855 & 21.785 & 21.783 & 21.932 & 21.857 \\
\hline Wheat midds & 9.571 & 9.576 & 9.206 & 9.394 & 5.833 & 5.839 & 5.371 & 5.607 & 2.094 & 2.102 & 1.536 & 1.822 \\
\hline $\begin{array}{l}\text { Dicalcium phosphate } \\
24.5 \% \mathrm{Ca} 18.5 \% \mathrm{P}\end{array}$ & 1.071 & 1.065 & 1.071 & 1.068 & 1.125 & 1.118 & 1.124 & 11.21 & 1.179 & 1.170 & 1.178 & 1.174 \\
\hline Limestone $38.4 \% \mathrm{Ca}$ & 5.786 & 2.895 & 2.971 & 2.932 & 7.318 & 3.662 & 3.755 & 3.700 & 8.851 & 4.426 & 4.545 & 4.484 \\
\hline Oyster shell $36.4 \% \mathrm{Ca}$ & --- & --- & 2.970 & 1.466 & --- & --- & 3.760 & 1.859 & --- & --- & 4.544 & 2.244 \\
\hline Coarse limestone $38.4 \% \mathrm{Ca}$ & --- & 2.89 & --- & 1.466 & --- & 3.661 & --- & 1.859 & --- & 4.430 & --- & 2.244 \\
\hline Mineral supplement ${ }^{1}$ & 0.050 & 0.050 & 0.050 & 0.050 & 0.050 & 0.050 & 0.050 & 0.050 & 0.050 & 0.050 & 0.050 & 0.050 \\
\hline Vitamin supplement ${ }^{2}$ & 0.100 & 0.100 & 0.100 & 0.100 & 0.100 & 0.100 & 0.100 & 0.100 & 0.100 & 0.100 & 0.100 & 0.100 \\
\hline Salt & 0.350 & 0.350 & 0.350 & 0.350 & 0.350 & 0.350 & 0.350 & 0.350 & 0.350 & 0.350 & 0.350 & 0.350 \\
\hline $\begin{array}{l}\text { DL-Methionine 99\% } \\
\text { (powder) }\end{array}$ & 0.126 & 0.126 & 0.126 & 0.126 & 0.129 & 0.129 & 0.130 & 0.129 & 0.132 & 0.132 & 0.133 & 0.133 \\
\hline Choline chloride $60 \%$ & 0.050 & 0.050 & 0.050 & 0.050 & 0.050 & 0.050 & 0.050 & 0.050 & 0.050 & 0.050 & 0.050 & 0.050 \\
\hline TOTAL $(\mathrm{kg})$ & 100.000 & 100.000 & 100.000 & 100.000 & 100.000 & 100.000 & 100.000 & 100.000 & 100.000 & 100.000 & 100.000 & 100.000 \\
\hline Nutrientes & \multicolumn{12}{|c|}{ Content in the feed } \\
\hline ME (kcal/kg feed) & 2.7500 & 2.7500 & 2.7500 & 2.7500 & 2.7500 & 2.7500 & 2.7500 & 2.7500 & 2.7500 & 2.7500 & 2.7500 & 2.7500 \\
\hline Crude protein (\%) & 15.55 & 15.55 & 15.55 & 15.55 & 15.55 & 15.55 & 15.55 & 15.55 & 15.55 & 15.55 & 15.55 & 15.55 \\
\hline Calcium (\%) & 2.6 & 2.6 & 2.6 & 2.6 & 3.2 & 3.2 & 3.2 & 3.2 & 3.8 & 3.8 & 3.8 & 3.8 \\
\hline Available phosphorus (\%) & 0.33 & 0.33 & 0.33 & 0.33 & 0.33 & 0.33 & 0.33 & 0.33 & 0.33 & 0.33 & 0.33 & 0.33 \\
\hline Methionine (\%) & 0.395 & 0.395 & 0.395 & 0.395 & 0.398 & 0.398 & 0.398 & 0.398 & 0.411 & 0.401 & 0.401 & 0.401 \\
\hline Methionine+cystine (\%) & 0.660 & 0.660 & 0.660 & 0.660 & 0.660 & 0.660 & 0.660 & 0.660 & 0.660 & 0.660 & 0.660 & 0.660 \\
\hline Lysine & 0.763 & 0.763 & 0.764 & 0.763 & 0.77 & 0.77 & 0.77 & 0.77 & 0.77 & 0.77 & 0.77 & 0.77 \\
\hline
\end{tabular}

1 - Mineral supplement per kg feed: zinc $54 \mathrm{mg}$, iron $54 \mathrm{mg}$, manganese $72 \mathrm{mg}$, copper $10 \mathrm{mg}$, iodine $0.61 \mathrm{mg}$, selenium $0.302 \mathrm{mg}$. 2 - Vitamin supplement per kg feed: Vit A 7,520 IU, Vit D3 1,816 IU, Vit E 8.4 mg, Vit k3 1.28 mg, Vit B1 1.34 mg, Vit B2 3.0 mg, Vit B6 1.66 mg, Vit B12 8.0 mcg, nicotinic acid 20 mg , calcium pantothenate $8.0 \mathrm{mg}$, folic acid $0.300 \mathrm{mg}$, biotin $0.04 \mathrm{mg}$. 
Pizzolante CC, Kakimoto SK, Saldanha ESPB, Laganá C, Souza HBA, Moraes JE

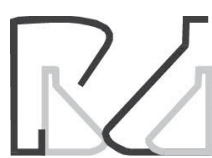

mass (\%), feed intake $(\mathrm{g})$, feed conversion ratio $(\mathrm{kg} /$ $\mathrm{dz}$ and $\mathrm{kg} / \mathrm{kg}$ ) and mortality (\%). Eggs from each experimental unit were daily collected and counted, and weekly weight. Feed residues were also weekly weighed.

Table 2 - Experimental treatments.

\begin{tabular}{|c|c|c|}
\hline Treatments & Calcium (\%) & Calcium sources* \\
\hline 1 & 2.6 & $100 \%$ FL $(0.44 \mathrm{~mm})$ \\
\hline 2 & 2.6 & $50 \% \mathrm{FL}(0.44 \mathrm{~mm})+50 \% \mathrm{CL}(2.40 \mathrm{~mm})$ \\
\hline 3 & 2.6 & $50 \% \mathrm{FL}(0.44 \mathrm{~mm})+50 \%$ OS $(2.19 \mathrm{~mm})$ \\
\hline 4 & 2.6 & $\begin{array}{l}50 \% \mathrm{FL}(0.44 \mathrm{~mm})+25 \% \mathrm{CL}(2.40 \mathrm{~mm}) \\
+25 \% \text { OS }(2.19 \mathrm{~mm})\end{array}$ \\
\hline 5 & 3.2 & $100 \% \mathrm{FL}(0.44 \mathrm{~mm})$ \\
\hline 6 & 3.2 & $50 \% \mathrm{FL}(0.44 \mathrm{~mm})+50 \% \mathrm{CL}(2.40 \mathrm{~mm})$ \\
\hline 7 & 3.2 & $50 \% \mathrm{FL}(0.44 \mathrm{~mm})+50 \%$ OS (2.19 mm) \\
\hline 8 & 3.2 & $\begin{array}{l}50 \% \mathrm{FL}(0.44 \mathrm{~mm})+25 \% \mathrm{CL}(2.40 \mathrm{~mm}) \\
+25 \% \text { OS }(2.19 \mathrm{~mm})\end{array}$ \\
\hline 9 & 3.8 & $100 \% \mathrm{FL}(0.44 \mathrm{~mm})$ \\
\hline 10 & 3.8 & $50 \% \mathrm{FL}(0.44 \mathrm{~mm})+50 \% \mathrm{CL}(2.40 \mathrm{~mm})$ \\
\hline 11 & 3.8 & $50 \% \mathrm{FL}(0.44 \mathrm{~mm})+50 \%$ OS $(2.19 \mathrm{~mm})$ \\
\hline 12 & 3.8 & $\begin{array}{l}50 \% \mathrm{FL}(0.44 \mathrm{~mm})+25 \% \mathrm{CL}(2.40 \mathrm{~mm}) \\
+25 \% \mathrm{OS}(2.19 \mathrm{~mm})\end{array}$ \\
\hline
\end{tabular}

*Calcium sources: $\mathrm{FL}=$ fine limestone; $\mathrm{CL}=$ coarse limestone; $\mathrm{OS}=$ Oyster shell.

Egg quality was evaluated at the end of four $28 \mathrm{~d}$ periods during three consecutive days, in a total of 36 eggs per treatment. Eggs were identified according to treatment and individually weighed in a $0.001 \mathrm{~g}$ precision digital scale. Eggs were then submitted to the laboratory to determine specific egg gravity, de yolk, albumen and eggshell percentages, yolk index $(\mathrm{YI})$, Haugh unit (HU), eggshell thickness (EST) and eggshell breaking strength (BS).

Specific egg gravity was determined by immersing the eggs in saline solutions with densities between 1.065 and $1.100 \mathrm{~g} / \mathrm{cm}^{3}$, in 0.005 gradients. Eggs were then broken, and their eggshell, albumen and yolk were separated and weighed.

Albumen quality was evaluated using Haugh units. Egg weight $(\mathrm{g})$ and albumen height $(\mathrm{mm})$ data were used to calculated Haugh unit according to the formula suggested by Standelman \& Cotterill (1986): HU= 100 $\log \left(H+7.57-1.7 W^{0.37}\right)$, where: $\mathrm{HU}=$ Haugh unit; $\mathrm{H}=$ albumen height $(\mathrm{mm})$ and $\mathrm{W}=$ egg weight $(\mathrm{g})$.

Yolk quality was evaluated in yolk index. Yolk diameter and height were measured and applied to the formula $\mathrm{YI}=\mathrm{YH} / \mathrm{YD}$, where: $\mathrm{Yl}=$ yolk index; $\mathrm{YH}=$ yolk height $(\mathrm{mm})$ and $\mathrm{YD}=$ yolk diameter $(\mathrm{mm})$.

Eggshells were washed under running water and dried in a forced-ventilation oven at $60{ }^{\circ} \mathrm{C}$ for $12 \mathrm{~h}$, and their thickness (including the membrane) was determined in three points of the egg equatorial region
Limestone and Oyster Shell for Brown Layers in Their Second Egg Production Cycle

using a $0.01 \mathrm{~mm}$ precision Mitutoyo micrometer. Eggshell was determined in a $0.001 \mathrm{~g}$ precision scale.

Eggshell breaking strength was evaluated in intact eggs using a specific cell coupled to a Texture Analyser TA. XT plus with probe to measure eggshell breaking strength (Cyl Stainless $2 \mathrm{~mm}$, code $P / 2$, pre-test velocity of $2 \mathrm{~mm} / \mathrm{s}$; test velocity of $1.0 \mathrm{~mm} / \mathrm{s}$, and posttest velocity of $40 \mathrm{~mm} / \mathrm{s}$ ) which recorded the strength required to break the eggshell in kgf.

In order to analyze the results, an experimental period of 112 days was established. Data were submitted to analysis of variance and means were compared by the test of Tukey at 5\% probability using SISVAR software package (Ferreira, 2000).

\section{RESULTS AND DISCUSSION}

The results of the analysis to determine particle size, in-vitro solubility and calcium levels in limestone and oyster shell are presented in Table 3. Particles were found to be uniform within each particle size class.

Table 3 - Particle-size composition, in-vitro solubility and calcium levels of calcium sources.

\begin{tabular}{lccc}
\hline Source & $\begin{array}{c}\text { Particle size } \\
(\mathbf{m m})\end{array}$ & $\begin{array}{c}\text { In-vitro } \\
\text { solubility (\%) }\end{array}$ & $\begin{array}{c}\text { Calcium } \\
\mathbf{( \% )}\end{array}$ \\
\hline Fine limestone & 0.44 & 31 & 38.4 \\
Coarse limestone & 2.40 & 28 & 38.4 \\
Oyster shell & 2.19 & 46 & 36.4 \\
\hline
\end{tabular}

$\mathrm{GMD}=$ geometric mean diameter.

The particle sizes of the calcium sources fine limestone, coarse limestone and oyster shell used in the present study were $0.44,2.40$ and $2.19 \mathrm{~mm}$, respectively. According to Ito (2006), particle size is a gross criterion, as it expresses only a mean value, and does not take into account sub-components of different sizes, which relative ratios can present wide variations. That author stresses that, on the other hand, when calcium sources are chosen according to their solubility values, the variation in the ratios of their sub-components and in their crystalline structure have already been considered and, therefore, solubility is a better decision-making criterion than particle size.

In-vitro solubility values obtained in the present study were $31 \%$ and $28 \%$ for fine and coarse limestone, respectively, and $46 \%$ for oyster shell. According to Scott (1991), the expected solubility percentages for fine limestone vary between $50 \%$ and $70 \%$, whereas for coarse limestone and oyster shell, the expected solubility is between $20 \%$ and $40 \%$.

The differences between the solubility values 
Pizzolante CC, Kakimoto SK, Saldanha ESPB, Laganá C, Souza HBA, Moraes JE

obtained in the present study and those mentioned in literature may be explained by the different particle sizes and hardness of calcium sources obtained from different regions, as softer limestone presents large particle size and high in-vitro solubility (Bertechini, 2006). Rabon \& Roland (1985) evaluated 44 different limestone and oyster shell products produced by nine different US companies, and found variations of up to $63 \%$ in their in-vitro solubility values when the same particle size was used in the comparisons.

Average minimum and maximum environmental temperatures were 19.5 and $31.5^{\circ} \mathrm{C}$ in house 1 and 19.2 and $30.3^{\circ} \mathrm{C}$ in house 2 . During the experimental period, a variation in environmental temperature range, recording minimum and maximum temperatures of 13 ${ }^{\circ} \mathrm{C}$ and $38{ }^{\circ} \mathrm{C}$, respectively.

There was a significant influence $(p<0.05)$ of house (blocks) on feed intake, feed conversion ratio per dozen eggs and feed conversion ratio per $\mathrm{kg}$ eggs. This indicates that the environments of the two houses were different; however, this effect was isolated (controlled) when a random block design was applied in the analysis of variance.

The analysis of variance did not detect significant differences nor interactions ( $p>0.05$ ) among the studied factors on the live performance of the layers. The following averages were obtained: egg weight= $70.85 \mathrm{~g}(\mathrm{CV}=2.54 \%)$; egg production $=81.27 \%(\mathrm{CV}=$ $8.37 \%)$; egg mass $=57.56 \mathrm{~g}(\mathrm{CV}=8.40 \%)$; average daily feed intake $=119.83 \mathrm{~g}(\mathrm{CV}=3.96 \%)$; feed conversion ratio per dozen eggs $=1.79(\mathrm{CV}=7.73 \%)$, feed conversion ratio per $\mathrm{kg}$ eggs $=2.10(\mathrm{CV}=7.43 \%)$ and mortality $=1.07 \%(C V=338 \%)$.

Results of studies on layer performance relate calcium levels to egg production and weight. In the present study, it was observed that both calcium dietary levels and the different particle size combinations of calcium sources did not influence performance, and that the daily average calcium intake of $3.11 \mathrm{~g} /$ day/bird, which was obtained at the lowest dietary calcium level, was sufficient to supply egg production requirements.

These results are consistent with the findings of Kussakawa et al. (1998), Faria et al. (2000), Jardim Filho et al. (2005), Ito et al. (2006) and Pizzolante et al. (2006), who tested different calcium levels and calcium source combinations in the diet of brown and/ or white layers in different production phases (initial, final, and after forced molting) and did not detect any influence on performance parameters during the entire experimental period. According to Jardim Filho et al. (2005), when calcium is deficient, layers tend

\section{Limestone and Oyster Shell for Brown Layers in Their} Second Egg Production Cycle

to maintain egg production, but eggshell quality is compromised.

There was no significant effect of any of the applied treatments ( $p>0.05)$ on internal egg quality, as measured by yolk and albumen percentages, Haugh unit, yolk index and color.

The main indicator of internal quality of table eggs is Haugh units, which represent albumen height corrected for egg weight. Despite the criticism of some authors, it is considered a standard egg quality measurement and it is virtually by the entire egg industry. Considering that no significant differences were observed in egg weight and albumen percentage, and that the results of studies on the effect of calcium on internal egg quality do not provide information on the influence of this mineral on albumen weight and percentage (Castillo et al., 2004, Jardim Filho et al., 2005, Hernández-Sánchez et al., 2006), it is assumed that both calcium levels and particle size composition of the used calcium sources were sufficient to maintain the internal egg quality of layers in their second production cycle. However, the obtained results disagree with those observed by Rodrigues et al. (1994), who verified an improvement in Haugh units when high calcium levels were added to the feed of layers in their second production cycle.

There was an isolated effect $(p<0.05)$ on external egg quality both of the particle size composition of calcium sources (Table 4) and of calcium levels in the experimental diets (Table 5). However, there was no interaction between these factors.

The effects of the particle size composition of calcium sources on the external egg quality of brown layers in their second production cycle are shown in Table 4.

Although the in-vitro solubility of fine limestone (31\%) presented an intermediate value between that of coarse limestone (28\%) and oyster shell (36\%), it was observed that external egg quality, except for breaking strength, improved when $50 \%$ fine limestone was replaced by $50 \%$ coarse limestone or by $50 \%$ oyster shell. These results suggest that particle size of the used sources may have interfered with calcium absorption, and consequently, with eggshell synthesis.

Considering that eggshell synthesis usually occur during the night, when birds usually do not eat, the use of calcium sources with lower solubility or larger particle size may promote better eggshell quality and/ or less utilization of calcium bone reserves. The results obtained in the present study are consistent with the concept that large particle size or low in-vitro solubility may increase calcium retention in layers and improve 
Pizzolante CC, Kakimoto SK, Saldanha ESPB, Laganá C, Souza HBA, Moraes JE

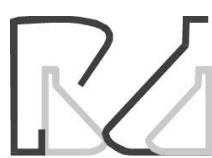

Limestone and Oyster Shell for Brown Layers in Their Second Egg Production Cycle

Table 4 - Average specific egg gravity (SG), eggshell thickness (EST), eggshell percentage (eggshell\%), eggshell weight per surface area (EWSA) and breaking strength (BS) of brown layers in their second production cycle fed different calcium sources and particle size compositions of calcium sources.

\begin{tabular}{|c|c|c|c|c|c|}
\hline \multirow{2}{*}{ Particle size composition of calcium sources } & \multicolumn{5}{|c|}{ Evaluated parameters } \\
\hline & SG $\left(\mathrm{g} / \mathrm{cm}^{3}\right)$ & EST $(\mathrm{mm})$ & Eggshell (\%) & EWSA (mg/cm2) & BS (g) \\
\hline $100 \% \mathrm{FL}^{1}$ & $1.077 \mathrm{~b}$ & $33.00 \mathrm{~b}$ & $8.12 \mathrm{~b}$ & $72.72 \mathrm{~b}$ & $3.790 a$ \\
\hline $50 \% \mathrm{FL}+50 \% \mathrm{CL}^{2}$ & $1.081 \mathrm{a}$ & $34.45 a$ & $8.51 a$ & $77.89 a$ & 4.105a \\
\hline $50 \% \mathrm{FL}+50 \% \mathrm{OS}^{3}$ & $1.081 \mathrm{a}$ & $34.39 a$ & $8.50 a$ & 74.73ab & $4.038 a$ \\
\hline $50 \% \mathrm{FL}+25 \% \mathrm{CL}+25 \%$ OS & $1.080 \mathrm{a}$ & $34.28 a b$ & $8.4 a b$ & $76.56 \mathrm{ab}$ & $4.03 \mathrm{a}$ \\
\hline Média geral & 1.080 & 34.03 & 8.38 & 75.48 & 3.992 \\
\hline CV $(\%)$ & 0.19 & 4.56 & 3.85 & 6.88 & 10.38 \\
\hline
\end{tabular}

Means followed by different letters in the same column are different by the test of Tukey $(p<0.05) .1-F L=f i n e ~ l i m e s t o n e ~(G M D=0.44 m m) .2-C L=c o a r s e$ limestone $(\mathrm{GMD}=2.40 \mathrm{~mm}) .3$ - OS= oyster shell $(\mathrm{GMD}=2.19 \mathrm{~mm})$

eggshell quality. Zhang \& Coon (1997) reported that limestone retention in the gizzard increased when its in-vitro solubility was low or when dietary calcium level increased, and that limestone in-vivo solubility was reduced as dietary calcium level increased. According to those authors, limestone sources with particle size larger than $0.8 \mathrm{~mm}$ and low in-vitro solubility (30 $50 \%$ ) were retained in the gizzard longer, increasing their in-vivo solubility and calcium retention in layers.

In a literature review, Roland (1986) concluded that particle size higher than $3 \mathrm{~mm}$ promoted similar eggshell quality, independently of calcium source (oyster shell and limestone), and that eggshell quality parameter values are lower when only fine particles are used, which is consistent with the results of the present study. Similar findings were obtained by Kussakawa et al. (1998), Oliveira (2002), Jardim Filho et al. (2005) and Ito (2006).

Cruz etal. (1991) used feeds containing $100 \%$ oyster shell and observed an increase in eggshell percentage relative to the other diets, which contained 25, 50, 75 or $100 \%$ de limestone. Kussakawa et al. (1998) also found higher eggshell percentage in egg of layers fed a diet with higher limestone relative to oyster shell (66\% coarse limestone $+33 \%$ oyster shell) as compared to those fed $100 \%$ oyster shell, suggesting that the use of the latter as the sole calcium source negatively affected thus parameter. The same authors verified higher specific egg gravity in eggs of layers fed $66 \%$ coarse limestone $+33 \%$ oyster shell as compared to those fed $66 \%$ oyster shell $+33 \%$ coarse limestone, and mention that specific egg gravity is influenced by different ratios of calcium sources and different particle sizes.

The isolated effect $(p<0.05)$ of dietary calcium levels on specific egg gravity, eggshell thickness, eggshell percentage, eggshell weight per surface area, and breaking strength are presented through regression equations in Table 5. An increasing linear effect $(p<0.05)$ was observed as dietary calcium levels increased (Figures 1 to 5 )

In the present study, it was observed that, when birds were fed higher dietary calcium levels, there was an increasing linear effect $(p<0.05)$ on eggshell quality parameters, confirming the results of other researchers, which obtained higher eggshell weight and better eggshell quality when layers increased their calcium intake as a result of the supply of higher calcium levels in the diet (Frost \& Roland, 1991; Clunies et al., 1992, Albano Jr, 2000, Abdallah et al., 1993, Costa et al., 2008). However, according to Clunies et al. (1992), increasing dietary calcium levels result in a linear increase in calcium retention and a quadratic increase in eggshell weight. Costa et al. (2008) evaluated dietary calcium levels between 3.0 and $5.0 \%$ and observed a significant effect on eggshell weight, and the best result was obtained with $4.3 \%$ calcium, but a linear increase in eggshell percentage as dietary calcium levels increased.

Table 5 - Regression equations of SG $\left(\mathrm{g} / \mathrm{cm}^{3}\right)$, EST $(\mathrm{mm})$, eggshell \%, EWSA $\left(\mathrm{mg} / \mathrm{cm}^{2}\right)$ and BS $(\mathrm{g})$ of brown layers in their second production cycle fed different calcium levels.

\begin{tabular}{lcc}
\hline Parameters & Equations & $\mathbf{R}^{\mathbf{2}} \mathbf{( \% )}$ \\
\hline Specific egg gravity $\left(\mathrm{g} / \mathrm{cm}^{3}\right)$ & $\mathrm{Y}=1.0722+0.002416 \mathrm{X}$ & 78.95 \\
Eggshell thickness $(\mathrm{mm})$ & $\mathrm{Y}=29.4910+1.4188 \mathrm{X}$ & 91.74 \\
Eggshell percentage $(\%)$ & $\mathrm{Y}=7.2154+0.3655 \mathrm{X}$ & 87.35 \\
Eggshell weight/surface area $\left(\mathrm{mg} / \mathrm{cm}^{2}\right)$ & $\mathrm{Y}=59.9041+4.8658 \mathrm{X}$ & 91.29 \\
Eggshell breaking strength $(\mathrm{g})$ & $\mathrm{Y}=2.7500+0.388 \mathrm{X}$ & 89.90 \\
\hline
\end{tabular}

\section{CONCLUSIONS}

Under the conditions of the present experiment, it was concluded that dietary calcium levels between 2.6 and $3.8 \%$ may be fed to layers with no effect on performance or internal egg quality, but in order to improve eggshell quality, brown layers in their second production cycle should be fed $3.8 \%$ dietary calcium. 


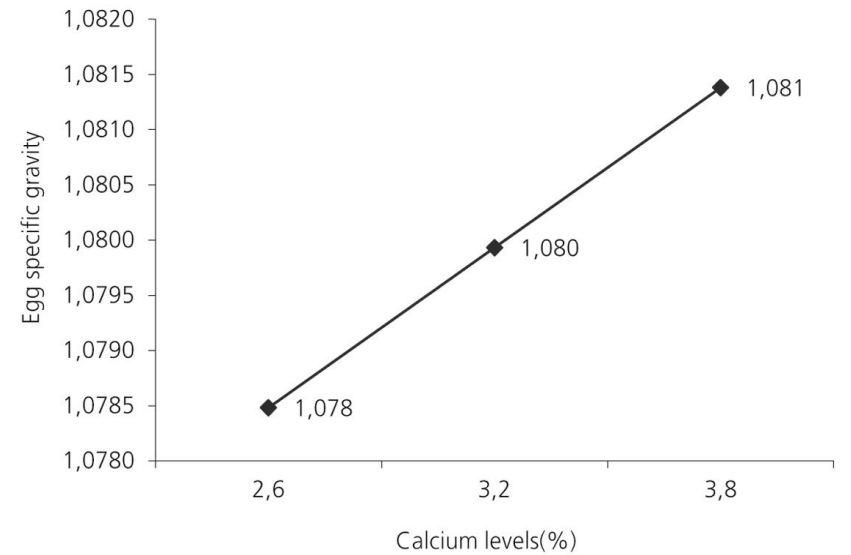

Figure 1 - Specific egg gravity $\left(\mathrm{g} / \mathrm{cm}^{3}\right)$ of brown layers in their second production cycle fed different calcium levels.

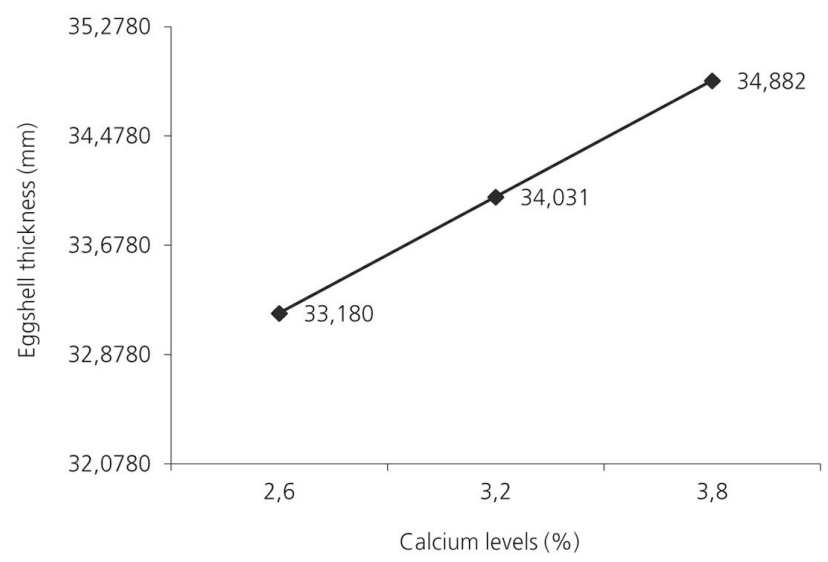

Figure 2 - Eggshell thickness ( $\mathrm{mm}$ ) of brown layers in their second production cycle fed different calcium levels.

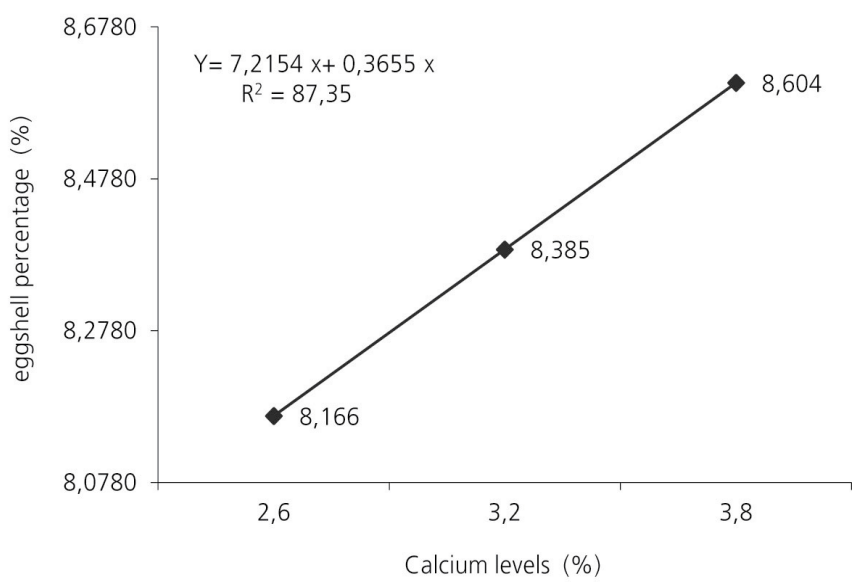

Figure 3 - Eggshell percentage (\%) of brown layers in their second production cycle fed different calcium levels.

Particle size composition of calcium sources significantly influenced external egg quality, which improved with the replacement of up to $50 \%$ fine limestone by coarse limestone and/or oyster shell.

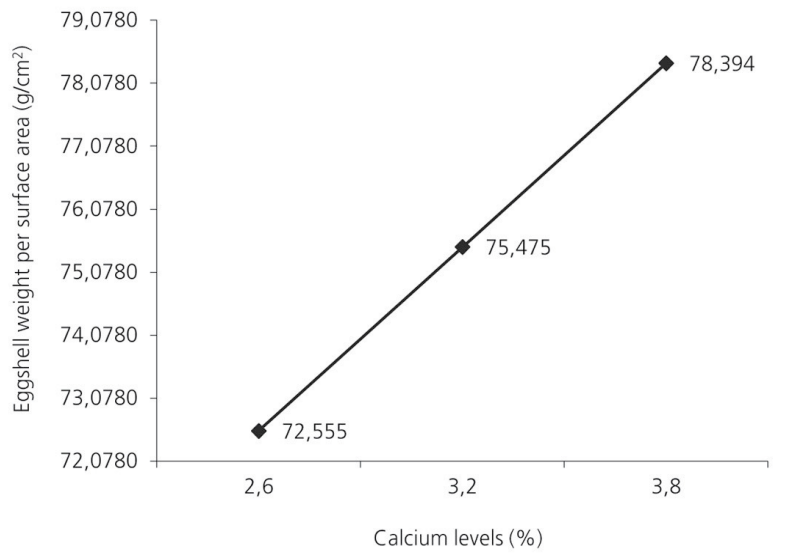

Figure 4 - Eggshell weight per surface area $\left(\mathrm{mg} / \mathrm{cm}^{2}\right)$ of brown layers in their second production cycle fed different calcium levels.

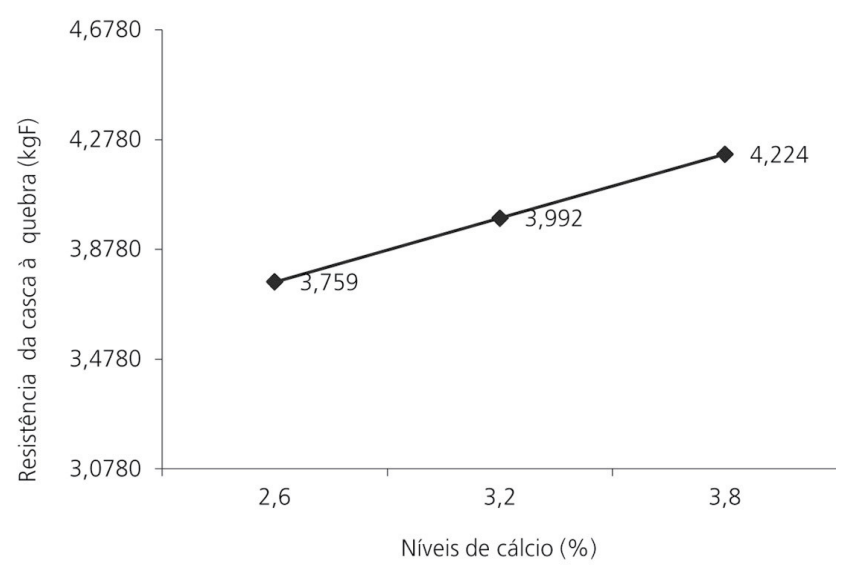

Figure 5 - Eggshell breaking strength (g) of brown layers in their second production cycle fed different calcium levels.

Most literature reports on calcium levels and/or sources derived from experiments carried out with white layers. Further studies should be carried out with brown layers in their second production cycle and with other nutrients related to calcium metabolism and/ or how calcium should be supplied to improve egg external quality, as the incidence of broken eggs is directly dependent on eggshell quality.

\section{REFERENCES}

Abdallah AG, Harms RH, El-Husseiny O. Performance of hens laying eggs with heavy or light shell weight when fed with different calcium and phophorus levels. Poultry Science 1993; 72(10):18811891.

Abdallah AG, Harms RH, El-Husseiny O. Various methods measuring shell quality in relation to percentage of cracked eggs. Poultry Science 1993; 72(11):2038-2043.

Albano Jr. M, Albuquerque R, Lima CG, Ghion E, Lima FR, Morais 
Pizzolante CC, Kakimoto SK, Saldanha ESPB, Laganá C, Souza HBA, Moraes JE

CSD. Desempenho e qualidade dos ovos de diferentes linhagens de poedeiras comerciais pós-muda forçada recebendo rações com níveis variáveis de cálcio. Brazilian Journal of Veterinary Research and Animal Science 2000; 37(4):334-338.

Bertechini AG, Fassani, EJ. Macro e microminerais na alimentação animal. Anais do $2^{\circ}$ Simpósio Sobre Ingredientes na Alimentação Animal; 2001; Campinas, São Paulo. Brasil. p.219-234.

Bertechini AG. Nutrição de monogástricos. Lavras: Ufla, Lavras; 2006.

Castillo C, Cuca M, Pro A. et al. Biological and economic optimum level of calcium in white leghorn laying hens. Poultry Science 2004; 83(6):868-872.

Cavalheiro ACL, Trindade DS, Oliveira SC, Arnt LM. Níveis de cálcio para poedeiras: resposta animal. Anuário Técnico do Instituto de Pesquisas Zootécnicas "Francisco Osório" 1982; 9:39-67.

Cheng TK, Coon C. Effect of calcium source, particle size, limestone solubility in vitro, and calcium intake level on layer bone status and performance. Poultry Science 1990; 69(12):2214-2219.

Clunies M, Parks M, Leeson S. Calcium and phosphorus metabolism and eggshell formation of hens fed different amounts of calcium. Poultry Science 1992; 71(3):482-489.

Costa FGP, Oliveira CFS, Dourado LRB, Lima Neto RC, Campos MASF, Lima AGVO. Níveis de cálcio em dietas para poedeiras semipesadas após o pico de postura. Revista Brasileira de Zootecnia 2008; 37(4):624-628.

Cruz FGG, Izel ACV, Rocha ASNC. Substituição da farinha de ostras por calcário em rações de poedeiras comerciais. Anais do $2^{\circ}$ Congresso Brasileiro de Avicultura; 1991; Brasília, DF. Brasil. p.183.

Dell'Lsola ATP, Baião NC. Cálcio e fósforo para galinhas poedeiras. Cadernos Técnico de Veterinária e Zootecnia 2001; 34:65-92.

Faria DE, Junqueira OM, Sakomura NK, Santana AE. Sistemas de alimentação e suplementação de farinha de casca de ostras sobre o desempenho e a qualidade da casca dos ovos de poedeiras comerciais. Revista Brasileira de Zootecnia 2000; 29(5):1394-1401.

Fassani EJ, Bertechini AG, Kato RK, Fialho ET, Geraldo A. Composição e solubilidade in vitro de calcários calcíticos de Minas Gerais. Ciência e Agrotecnologia 2004; 28(4):913-918.

Fassani EJ. Características físico-químicas de calcários calcíticos do Estado de Minas Gerais utilizados em rações de poedeiras [doutorado]. Lavras (MG): Universidade Federal de Lavras; 2003.

Ferreira DF. Sistema para análise de variância para dados balanceados (SISVAR). Lavras: UFLA; 2000. 92 p.

Frost TJ, Roland DA Sr. The influence of various calcium and phosphorus levels on tibia strength and eggshell quality of pullets during peak production. Poultry Science 1991; 70(4):963-969.

Geraldo A, Bertechini AG, Kato RK, Brito JAG, Fassani EJ. Níveis de cálcio e granulometria do calcário para frangas e seus efeitos sobre a produção e qualidade de ovos. Revista Brasileira de Zootecnia 2006; 35(4):1720-1727 Limestone and Oyster Shell for Brown Layers in Their
Second Egg Production Cycle

Hernandez-Sanchez J, Cuca-Garcia M, Pró-Martinez, GonzálezAlcorta M, Becerril-Pérez, C. Nivel óptimo biológico y económico de calcio en gallinas Leghorn blancas de segundo ciclo de postura biological and economic optimum level of calcium in white leghorn of second cycle laying hens. Agrociência 2006; 40(1):49-57.

Ito DT, Faria DE, Kuwano EA, Junqueira OM, Araújo LF. Efeitos do fracionamento do cálcio dietário e granulometria do calcário sobre o desempenho e qualidade dos ovos de poedeiras comerciais. Acta Scentarium Animal Science 2006; 28(2):187-195.

Ito RI. Aspectos Nutricionais Relacionados à Qualidade da Casca de ovos. Anais do $2^{\circ}$ Curso de Atualização em Avicultura para Postura Comercial; 2006; Jaboticabal, São Paulo. Brasil. p.77-98.

Jardim Filho RM, Stringhini JH, Café MB, Leandro NSM, Cunha WCP, Nascimento Jr O. Influência das fontes e granulometria do calcário calcítico sobre o desempenho e a qualidade da casca dos ovos de poedeiras comerciais. Acta Scientiarum Animal Science $2005 ; 27(1): 35-41$

Junqueira OM, Rodrigues EA. Balanço de cálcio e fósforo em poedeiras comerciais. Anais do $3^{\circ}$ Curso de atualização em avicultura para postura comercial; 2004; Jaboticabal, São Paulo. Brasil. p.107-120.

Kussakawa KCK, Murakami AE, Furlan AC. Combinações de fontes de cálcio em rações de poedeiras na fase final de produção e após muda forçada. Revista Brasileira de Zootecnia 1998; 27(3):572-578.

Leeson S, Summers JD. Commercial poultry nutrition. Guelph: University Books; 1997. 355p.

Leeson S, Summers JD. Feeding programs for broiler chickens. In: Leeson S, Summers JD.. Commercial poultry nutrition. Guelph: Publ. University Books; 2005. p. 229-296.

Miles R. Fatores nutricionais relacionados a qualidade da casca dos ovos. Anais do Simpósio Goiano de Avicultura; 2000; Goiânia, Goiás. Brasil. p.173-195.

Miles RD. Gravedad específica del huevo-establecimento de un programa de verificación. generalidades sobre la calidad del cascarón de huevo. Soya: Associación Americana de Soya; 1993. p.1-8.

Murata LS, Ariki J, Santana AP, Jardim Filho RM. Níveis de cálcio e granulometria do calcário sobre o desempenho e a qualidade da casca de ovos de poedeiras comerciais. Revista Biotemas 2009; 22(1):103-110.

National Research Council - NRC. Nutrient requirements of poultry. Washington: National Academy Press; 1994. 156p.

Oliveira JR, Bertechini AG, Fassani EJ. Níveis de cálcio em dietas para poedeiras leves e semipesadas no segundo ciclo de produção. Ciência e Agrotecnologia 2002; 26(5):1060-1067.

Pizzolante CC, Garcia EA, Laganá C, Saldanha ESPB, Deodato AP, Faitarone $A B G$, Scherer MR, Batista L. Effect of the calcium level and limestone particle size on the performance of semi-heavy layers in the second cycle of egg production. Brazilian Journal of Poultry Science 2006; 8(3):173-176. 
Rabon Jr HW, Roland DA. Solubility comparisons of limestones and oyster shells from different companies and the short term effects of switching limestones varying in solubity in egg specific gravity. Poultry Science 1985; 64(Suppl. 1):37-38.

Rodrigues EA, Junqueira OM, Valério $\mathrm{M}$, Andreotti $\mathrm{MO}$, Cancherini LC; Faria DE, Filardi RS. Níveis de cálcio em rações de poedeiras comerciais no segundo ciclo de postura. Acta Scientiarum Animal Sciences 2005; 27(1):49-54.

Rodrigues PB, Bertechini AG, Oliveira BL. Estudo de fatores que afetam o desempenho e a qualidade do ovo de poedeiras comerciais no $2^{\circ}$ ciclo. Anais da Conferência Apinco de Ciência e Tecnologia Avícola; 1994. Campinas, São Paulo. Brasil. p.45-46.

Rodrigues PB. Fatores nutricionais que influenciam a qualidade do ovo no segundo ciclo de produção [mestrado]. Lavras (MG): Universidade Federal de Lavras; 1995. 156p.

Roland DA, Bryant M. Optional shell quality possible without oyster shell. Feedstuffs 1999; 71(11):18-19.

Roland DA. Egg shell quality III: calcium and phosphorus requirements of commercial leghorns. World's Poultry Science Journal 1986; 42(2):154-165.

Roland Sr DA, Farmer M. Egg shell quality. II - Importance of time of calcium intake with emphasis on broiler breeders. World's Poultry Science Journal 1984; 40(3):255-60.

Rostagno HS, Albino LFT, Donzele JL, Gomes PC, Oliveira RF, Lopes DC, Ferreira AS, Barreto SLT. Tabelas brasileiras para aves e suínos: composição de alimentos e exigências nutricionais. Viçosa (MG): Universidade Federal de Viçosa; 2005.

Scott M. How can calcium be supplied to high producing hens? Feedstuffs 1991; 63(39):16-18.

Standelman WJ, Cotterill OJ. Egg science and technology. New York: Food Products Press; 1986. 499 p.

Zanotto DL, Bellaver C. Método de determinação da granulometria de ingredientes para uso em rações de suínos e aves [comunicado técnico, CT/21]. Concórdia: Embrapa-CNPSA; 1996. 5p. [acesso 2006 jul]. Disponível em: http://www.cnpsa.embrapa.br/sgc/sgc_ publicacoes/cot215.pdf.

Zhang B, Coon NC. The relationship of calcium intake, source, size, solubility in vitro and in vivo, and gizzard limestone retention in laying hens. Poultry Science 1997; 76(12):1627-1840. 

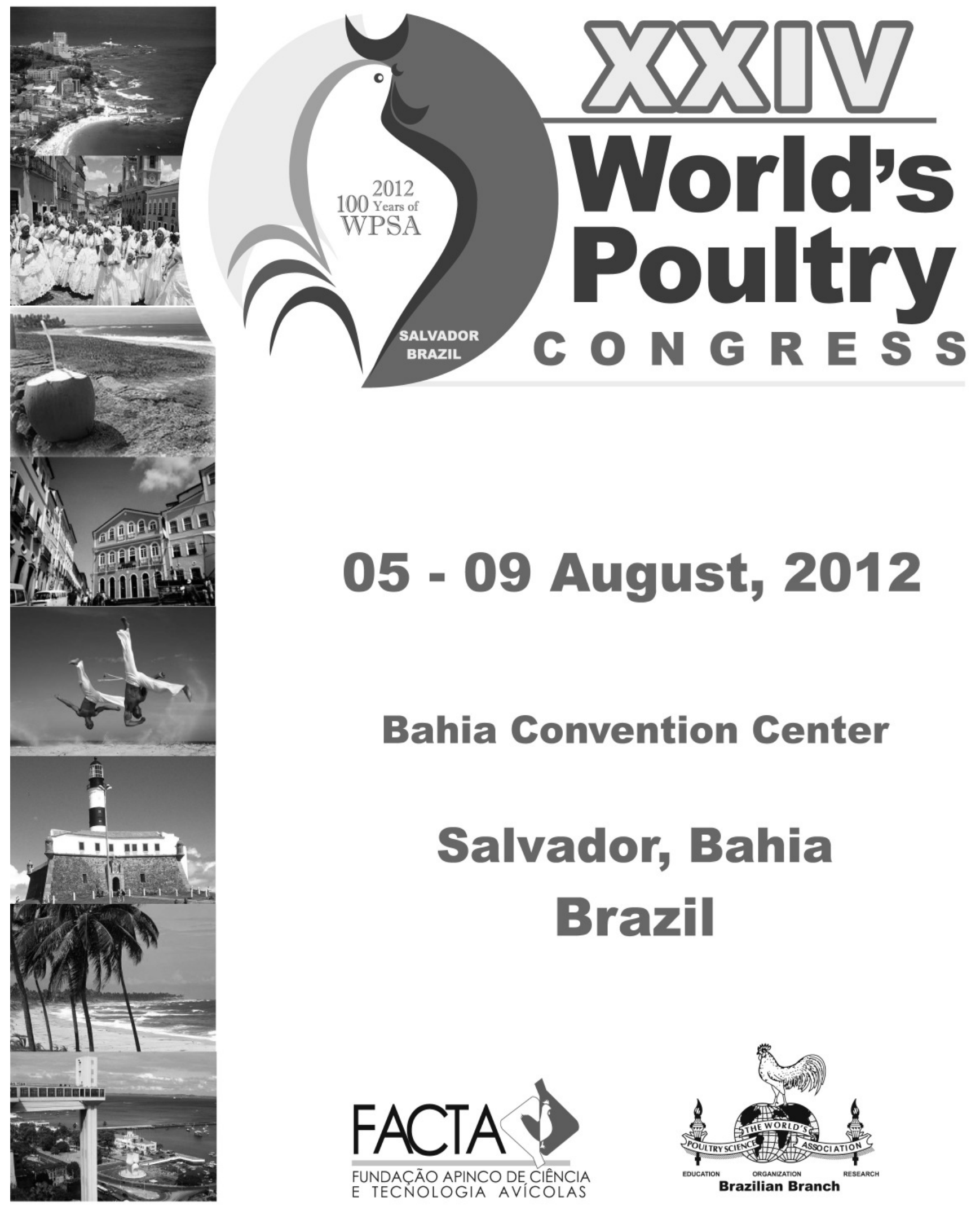

\title{
05 - 09 August, 2012
}

\author{
Bahia Convention Center
}

\section{Salvador, Bahia}

Brazil
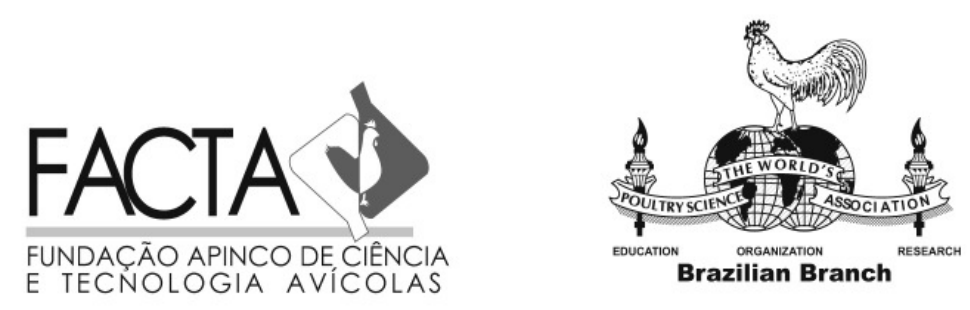

\section{WWW.WPG2012.COM}

